\title{
Faktor Atopi dan Asma Bronkial pada Anak
}

\author{
Sjawitri P Siregar
}

Prevalensi penyakit alergi seperti asma, rinitis alergi, dermatitis atopi, alergi obat dan alergi makanan meningkat di banyak negara. Dermatitis atopi dan alergi makanan timbul pada usia $<2$ tahun sedangkan asma dan rinitis alergi sekitar 6-12 tahun. Dermatitis atopi timbul paling dini sekitar 6 bulan dan $50 \%-80 \%$ akan berkembang menjadi asma di kemudian hari, bila mereka mempunyai orang tua atopi (allergic march). Pada Makalah ini akan dibahas faktor atopi dan mengenal, petanda biologis, dan faktor risiko alergi saat usia dini sehingga awitan penyakit asma dapat ditunda.

Kata kunci: Penyakit alergi - allergic march - imunopatologi inflamasi alergik

$\mathcal{P}$ aradigma masa kini mengenai patogenesis penyakit alergi adalah alergi berkembang hanya pada individu yang mempunyai predisposisi genetik setelah terpapar oleh alergen. Banyak faktor yang dapat mencetuskan penyakit alergi seperti faktor lingkungan misalnya alergen, infeksi, polusi dan lain-lain yang dapat memulai sensitisasi alergi dan menimbulkan manifestasi klinis. Oleh karena prevalens penyakit alergi meningkat di banyak negara sedangkan faktor genetik belum dapat dipengaruhi, maka yang dapat dimanipulasi adalah faktor lingkungan. Prevalens asma di populasi 3-4\% sedangkan rinitis 20\%. Dold dkk. melaporkan bila salah satu orangtua dengan dermatitis atopi (DA), maka kemungkinan anaknya juga akan menderita DA 3,4 kali lebih tinggi bila (OR 3,4) dibandingkan dengan salah satu orang tua dengan asma $(\mathrm{OR} 1,5)$ atau rinitis alergi (OR 1,4).

Dermatitis atopi adalah penyakit menahun dengan angka kejadian $10 \%$ dan sering merupakan manifestasi klinis pertama penyakit atopi dan mempunyai awitan pada tahun pertama kehidupan (sekitar usia 6 bulan). Penyakit kulit ini mempunyai predisposisi genetik atopi atau atopi pada keluarga sebesar $80 \%$, dan $40-80 \%$

Staf Pengajar Subbagian Alergi Imunologi Bagian Ilmu kesehatan Anak FKUI/RSCM

\footnotetext{
Alamat korespondensi:

Dr. Syawitri P. Siregar, SpA(K)

Jl. Salemba No. 6, Jakarta 10430, Indonesia.

Telpon: (021) 391 4126. Fax.: (021) 3914126.
}

anak dengan DA akan berkembang menjadi asma atau rinitis alergi di kemudian hari. Dermatitis atopi dan alergi makanan adalah penyakit alergi yang timbul pertama dan sering timbul pada usia tahun pertama kehidupan seorang anak yang di kemudian hari akan berkembang menjadi alergi respiratorik; gejala yang progresif ini disebut allergic march. Akan tetapi pada beberapa golongan anak alergi saluran napas merupakan gejala pertama. Pada penelitian kami terdapat 3932 anak atopi dengan sebaran asma dan rinitis alergi paling banyak usia 6-12 tahun sedangkan DA di bawah usia 2 tahun. Awitan alergi makanan di bawah usia 1 tahun, sedangkan awitan asma dan rinitis terbanyak di antara usia 2-4 tahun.

Untuk mencegah perkembangan DA pada anak usia dini menjadi asma di kemudian hari telah dilakukan penelitian multisenter (Early Treatment of Atopic Children $=$ ETAC). Pada makalah ini akan dibahas faktor atopi dan terjadi faktor risiko alergi saat usia dini sehingga awitan asma dapat diperlambat, karena bila awitan asma terjadi pada usia di bawah 3 tahun akan mempengaruhi perkembangan serta terjadi perubahan tingkah laku dibandingkan dengan anak yang awitan asmanya lebih tua.

\section{Faktor Prenatal}

\section{Pengaruh lingkungan intrauterin}

Lingkungan intrauterin dilengkapi dengan sistem 
imunologik untuk mempertahankan janin terhadap penolakan sel $\mathrm{T}$ dari ibunya sehingga janin dapat tumbuh. Telah diketahui bahwa Interleukin-4 (IL-4), Interleukin-5 (IL-5), dan Interleukin-10 (IL-10) terdapat dalam uterus dan cairan amnion. Sitokin ini meregulasi respons imun maternal, misalnya IL- 4 dan IL-5 adalah sitokin dari sel Th-2 yang berfungsi menekan IFN- $\alpha$ (interferon- $\alpha$ ) Tumor Necrosis Factor$\alpha(\mathrm{TNF} \alpha)$ dari sel Th-1 ibu yang bersifat sitotoksik.

Sitokin IL-4 dan IL-5 yang melindungi janin dari efek sitotoksik akan mempengaruhi pula pengembangan sistem imun janin, karena kadar sitokin Th-2 dan IL-10 akan mengurangi IFN- $\alpha$, sitokin Th- 1 dari janin dan ibu. Efek ini akan meningkatkan sitokin Th-2 yang akan berperan dalam proses alergi. Tambahan lagi bila ibu seorang penderita alergi yang akan meningkatkan Th-2 plasenta kejadian tersebut dapat menjelaskan bahwa risiko janin untuk alergi akan lebih besar diturunkan dari ibu, dibandingkan bila ayah yang alergi.

\section{Diet ibu hamil}

Sensitisasi sudah terjadi sejak dalam kandungan, hal ini dapat dibuktikan yaitu terjadinya reaksi alergi makanan pada neonatus yang baru pertama kali mendapat susu sapi. IgE dari ibu tidak dapat melewati sawar plasenta, sedangkan partikel protein susu sapi yang beredar dalam sirkulasi darah ibu dapat melewati sawar plasenta yang kemudian akan merangsang limfosit janin. Ini dapat dibuktikan karena terdapat proliferasi limfosit tali pusat neonatus. Hal ini menunjukkan bahwa sensitisasi sudah terjadi semasa janin masih dalam uterus. Bila kadar imunoglobin $\mathrm{E}$ tali pusat $>0,9 \mathrm{kU} / \mathrm{l}$ dan mempunyai lebih dari 2 anggota keluarga yang atopi maka anak tersebut akan mempunyai faktor risiko untuk perkembangan penyakit atopi. Bayi baru lahir sudah tersensitisasi dalam kandungan bila kadar IgE spesifik tali pusat $>0,35 \mathrm{kU} / \mathrm{l}$. Kadar IgE tali pusat juga tinggi pada ibu hamil yang perokok. Sehingga dapat disimpulkan bahwa kadar IgE tali pusat dapat dipakai sebagai faktor peramal dugaan sensitisasi dini.

Chandra dkk. mengamati 109 bayi yang berasal dari keluarga atopi sampai berumur 1 tahun. Bila ibu diberikan diet susu sapi, telur, ikan, kacang semasa kehamilan trimester ketiga dan semasa laktasi, dan bayi mendapat air susu ibu eksklusif sampai umur 6 bulan, maka prevalens DA pada bayi tersebut sangat rendah. Pernyataan ini kemudian dibantah bahwa ibu yang diberikan diet pada kehamilan trimester ketiga akan menghindarkan bayinya dari penyakit alergi hanya sampai umur 5 tahun.

\section{Merokok saat hamil}

Ibu yang merokok saat hamil akan melahirkan bayi prematur yang akan mempunyai ukuran paru lebih kecil dan akan mempunyai faktor risiko mengi pada usia neonatus, di samping itu asap rokok akan mengurangi fungsi paru bayi. Dengan menggunakan teknik tertentu dapat dibuktikan bahwa sudah terdapat obstruksi saluran napas derajat ringan pada bayi usia 3 hari bila ibunya perokok waktu hamil. Penelitian juga membuktikan bahwa bayi prematur dari ibu perokok waktu hamil akan rentan terhadap infeksi saluran napas disebabkan oleh virus, dan karena IgE tali pusat bayi ini tinggi $>0,9 \mathrm{IkU} / \mathrm{l}$.

\section{Faktor Pascanatal}

\section{Diet}

Insidens alergi makanan tertinggi pada usia tahun pertama kehidupan dan sebagian besar alergi makanan akan sembuh sekitar usia 3 tahun. Kecuali untuk beberapa makanan seperti kacang, ikan laut akan menetap seumur hidup. Dari 150 anak alergi makanan, $42 \%$ berusia di bawah 2 tahun dan hanya 3\% berusia di atas 12 tahun. Zeiger dan Heller pada studi kontrol terhadap 103 bayi yang diamati sampai berumur 7 tahun; pada ibunya diberikan diet susu sapi, telur, gandum selama masa laktasi, maka pada usia 1 tahun terdapat perbedaan bermakna antara 2 kelompok terhadap kejadian DA dan alergi makanan. Alergi susu sapi akan berkurang sekitar usia 2 tahun, tetapi pada usia 7 tahun tidak nampak perbedaan prevalens antara DA dan alergi makanan pada 2 kelompok tersebut. Kesimpulannya yaitu diet hipoalergenik waktu menyusukan bayi akan menurunkan prevalens alergi makanan dan DA pada usia dini.

Oehling dkk. melaporkan bahwa 8,5\% dari 284 anak asma disebabkan oleh alergi makanan, dan terbanyak sensitisasi terjadi pada tahun pertama kehidupan, dan penyebab makanan yang tersering 
adalah telur. Dermatitis atopi dengan uji kulit positip terhadap telur pada usia dini akan meningkatkan derajat hipersensitivitas seorang anak untuk mengidap asma di kemudian hari. Penelitian lain di National Jewish Center melaporkan bahwa penelitian prospektif selama 18 tahun terhadap 410 anak asma, diantaranya 68\% mempunyai riwayat alergi makanan, sedangkan anak dengan DA dan DBPCFC positip akan mempunyai risiko asma dan alergi. Penelitian Subbagian Alergi-Imunologi IKA mendapatkan DA terjadi pada umur kurang dari 1 tahun jika awitan maka akan mendapatkan alergi respiratorik (rinitis alergi dan atau asma) di kemudian hari, dan penundaan pemberian telur setelah umur 1 tahun akan melindungi anak terhadap risiko alergi respiratorik. Bagaimana peran makanan dapat mencetuskan serangan asma belum diketahui dengan pasti. Beberapa hipotesis menerangkan bahwa anak dengan DA dan alergi makanan akan mempunyai kadar histamin yang tinggi di dalam darahnya, karena mediator inflamasi sel mast. Teori tersebut lemah karena mediator akan cepat dimetabolisme. Kemungkinan lain adalah alergen yang dimakan akan mencapai sel inflamasi di saluran napas.

Alergi makanan kebanyakan dihubungkan dengan IgE spesifik yang dapat diperiksa secara invitro (RAST) atau dengan uji kulit. Uji kulit negatif mempunyai nilai prediktif yang tinggi dengan gejala klinik, sebaliknya uji kulit mempunyai nilai prediksi positip sebesar 50\%. Serangan asma yang tercetus akibat menghirup gandum yang sedang dibakar (baker's asthma), biasanya uji kulit terhadap gandum akan positip juga. Seorang yang alergi terhadap ikan akan mengalami serangan asma bila ia menghirup uap gorengan ikan.

\section{Paparan Aeroalergen}

\section{Polusi}

Data mengenai paparan polusi udara hubungannya dengan asma dan rinitis alergik masih kontroversi. Polusi udara oleh ozone, nitrogen dioksid, dan sulfur dioksid dikenal bersifat iritasi terhadap saluran napas dan akan memperberat asma karena akan meningkatkan reaksi hipersensitivitas non spesifik. Tetapi tidak demikian halnya dengan penelitian yang diadakan di Jerman, yaitu anak yang tinggal di Jerman Timur yang lebih banyak menghirup udara polusi mempunyai insiden asma rendah dibandingkan anak yang tinggal di Jerman Barat yang udaranya lebih bersih.

\section{Aeroalergen}

Aeroalergen sangat berperan pada asma dan rinitis alergik. Alergen rumah seperti tengu debu rumah (Dermatophagoides pteronyssinus, Dermatophagoides farinae, Euroglyphus, dan Blomiantropicalis), serpihan binatang piaraan, kecoa dan jamur merupakan aeroalergen tersering sebagai penyebab penyakit alergi. Prevalens tengu debu rumah berbeda pada tiap negara tetapi tengu debu rumah berkembang biak pada suhu hangat dan lembab. Prevalens tengu debu rumah sebagai penyebab asma di Meksiko sebesar 5\%, Atlanta $66 \%$ dan Papua $91 \%$. Enam puluh persen sampai $80 \%$ asma anak akan alergi terhadap 1 atau lebih aeroalergen yang dibuktikan dengan uji kulit positip. Aeroalergen di dalam rumah (indoor) di berbagai negara tidak sama, seperti laporan dari Subbagian Alergi-Imunologi IKA RS Cipto Mangunkusumo Jakarta, aeroalergen terbanyak adalah tengu debu rumah $(45 \%)$, debu rumah $(37 \%)$, serpihan binatang piaraan kucing, anjing, ayam dan burung (26\%), dan jamur 6\%. Sedangkan di Amerika, aeroalergen yang terbanyak adalah alteraria $(38 \%)$, kecoa $(36 \%)$, tengu debu rumah (35\%), kucing (24\%), dan anjing (16\%).

Pada DA tengu debu rumah juga turut berperan karena terdapat limfosit $T$ spesifik tengu debu rumah yang meningkatkan proliferasi sel $T$ helper yang akan meningkatkan sel eosinofil dan produksi IL-5. Kesimpulannya ialah sensitisasi tengu debu rumah yang dimulai usia bayi pada DA akan berisiko untuk berkembang menjadi alergi respiratorik di kemudian hari dengan alergen yang sama. Aeroalergen asap rokok juga sangat berperan mencetuskan serangan asma dan rinitis alergi.

\section{Virus}

Infeksi virus respiratory syncytial (RSV) sering menyebabkan bronkiolitis pada bayi usia 3-6 bulan dan $75 \%$ dari mereka akan mengalami mengi pada usia 2 tahun, 50\% masih mengi pada usia 3 tahun dan $40 \%$ akan tetap mengi sampai usia di atas 5 tahun. Infeksi dengan RSV akan menyebabkan kerusakan epitel saluran napas yang akan mempermudah absorbsi aeroalergen dan pembentukan antibodi IgE spesifik RSV, 
yang dapat menyebabkan degranulasi sel mast dan akan melepaskan mediator di saluran napas yang akan menyebabkan spasme bronkus dan penumpukan sel eosinofil. Pada anak besar lebih berperan rhinovirus, adenovirus, dan parainfluenza virus yang merupakan penyebab eksaserbasi asma pada $80-85 \%$ pasien. Di antara bayi yang meninggal akibat infeksi RSV, pada autopsi terdapat tumpukan limfosit dan sel eosinofil di paru yang menunjukkan proses inflamasi dan ditemukan antibodi RSV IgE spesifik di sekret nasofaring serta peningkatan histamin. Insidens mengi akan bertambah bila terdapat kombinasi alergen $\mathrm{IgE}$ spesifik antibodi dan infeksi virus RSV atau Rhinovirus.

Bronkiolitis yang disebabkan RSV pada usia dini akan berkembang menjadi asma bila ditemukan antibodi RSV IgE spesifik dalam sekret hidung. Bila mengi menetap apakah disebabkan IgE spesifik RSV atau $\mathrm{IgE}$ spesifik alergen lain (seperti debu rumah, tengu debu rumah), telah dibuktikan bahwa asma pada anak berumur 7 tahun mempunyai lebih dari dari 2 macam aeroalergen positip dengan uji kulit.

\section{Imunopatologi Inflamasi Alergik}

Mekanisme imun yang berperan adalah mekanisme tipe I klasifikasi Gell dan Coombs yang diperankan oleh antibodi IgE. Imunoglobulin E ini mempunyai reseptor pada sel mast, basofil, sel limfosit $T$, sel makrofag dan sel eosinofil. Walaupun daya ikatnya dengan sel mast mempunyai afinitas paling kuat. Jaringan saluran napas, saluran cerna, kulit, dan mata banyak mengandung sel-sel tersebut di atas. Seorang yang menderita riwayat atopi akan membuat antibodi IgE terhadap alergen tersebut, bila ia terpajan dengan alergen tersebut. Antibodi IgE yang terbentuk akan terikat pada sel mast dan sel lainnya. Bila di kemudian hari ia terpajan kembali dengan alergen yang serupa, maka alergen tersebut akan terikat pada IgE yang sudah terikat pada sel mast yang sudah tersentitisasi dan akan terjadi fusi granula dengan membran sel mast sehingga terjadi degranulasi. Akibatnya mediator yang sudah ada dalam granula keluar dari sel mast. Granula yang sudah ada ini adalah histamin yang mempunyai efek pelebaran pembuluh darah di mukosa sehingga terjadi pembengkakan saluran napas dan terjadi perembesan cairan ke jaringan sekitarnya. Pada saluran napas akan menimbulkan gejala sumbatan hidung, pilek, batuk sedangkan pada kulit pembengkakan dan kemerahan disertai rasa gatal. Selain histamin dilepaskan juga mediator lain seperti kemotaktik eosinofil (ECF-A) dan faktor kemotaktik neutrofil (NCF) yang akan menarik sel eosinofil dan sel netrofil ke tempat alergen berada, dengan tujuan memfagosit alergen. Tetapi pada reaksi alergi ada beberapa enzim dalam sel eosinofil yang akan merusak sel epitel mukosa pejamu. Reaksi yang terjadi ini disebut reaksi alergi fase cepat (RAFC) karena terjadi segera yaitu beberapa detik sampai beberapa menit dan berakhir 1-2 jam kemudian setelah terpajan dengan alergen. Bersamaan dengan lepasnya mediator dari sel mast juga terjadi aktivasi enzim fosfolipase yang ada pada membran sel mast, basofil yang akan mengubah fosfolipid yang ada pada membran sel menjadi asam arakidonat yang kemudian dimetabolisme oleh tubuh. Hasil metabolit ini antara lain adalah prostaglandin dan leukotrien yang disebut mediator yang terbentuk kemudian atau disebut juga sebagai slow reacting substance of anaphylaxis (SRS-A). Mediator ini akan menarik sel-sel radang ke tempat alergen berada dan juga meningkatkan permeabilitas dan pelebaran pembuluh darah, sehingga terjadi inflamasi alergi.

Pada reaksi inflamasi di atas terdapat berbagai produk aktivasi sel inflamasi yang disebut petanda biologis (PB). Kadarnya akan berhubungan dengan derajat inflamasi dan aktivasi sel inflamasi. Petanda biologis ditemukan dalam darah, jaringan sekitar inflamasi seperti cairan bilas bronkus, sputum, sekret hidung dan cairan skin window. Petanda biologis masuk ke dalam sirkulasi akibat kebocoran di tempat reaksi alergi. Berbagai sel seperti eosinofil, basofil, mastosit, sel $\mathrm{T}$ dan mediator sitokin, leukotrien, granula asal sel dan molekul adhesi dikenal sebagai PB alergi. Sel limfosit $\mathrm{T}$ yang berada di mukosa saluran napas, dan kulit mempunyai reseptor IgE dengan afinitas rendah. Dikenal 2 macam sel $T$ helper yaitu sel Th-1 dan sel Th-2. Sel Th-1 akan menghasilkan sitokin IFN- $\alpha$ sedangkan sel Th- 2 menghasilkan sitokin Interleukin 4 (IL-4) dan Interleukin-5 (IL-5). Interleukin-4 merangsang pembentukan IgE dan juga ekspresi CD23 (reseptor IgE dengan afinitas rendah pada sel limfosit B dan monosit) serta menginduksi ekspresi Vascular Cellular Adhesion Molecul-1 (ICAM1) dan kelangsungan hidup eosinofil serta peningkatan penglepasan histamin.

Eosinofil beredar di sirkulasi dan menuju ke organ 
target dengan bantuan histamin yang dilepaskan dari sel mast/sel basofil. Eosinofil akan menembus pembuluh darah dengan bantuan faktor kemotaksis dan molekul adhesi yang terdapat pada endotel pembuluh darah. Setelah menembus pembuluh darah, sel target yang mengekspresikan molekul adhesi memberi jalan pada sel eosinofil untuk kembali ke tempat sel mast semula. Eosinofil yang diaktifkan pada reaksi inflamasi alergi melepaskan mediator major basic protein (MBP), myelopreoxidase (MPO), eosinophilic cationic protein (ECP), eosinophilperoxidase (EPO) yang juga PB. major basic protein merusak sel epitel mukosa setempat. Kerusakan epitel ini mengakibatkan ujung saraf eferen terpapar sehingga mukosa menjadi hiperaktif, artinya mudah terangsang faktor non spesifik seperti asap rokok, bau bauan, perubahan cuaca dan garukan pada kulit; ECP dapat dipakai sebagai petanda keterlibatan eosinofil pada reaksi alergi, karena ECP dapat dipakai sebagai petanda keterlibatan eosinofil pada reaksi alergi, karena ECP pada anak alergi akan tinggi daripada anak normal. Pada provokasi anak asma dengan alergen akan meningkatkan kadar ECP dan PEF dan akan berkurang setelah diberikan inhalasi steroid. Pada fase akut DA kadar ECP meningkat dan akan berkurang pada fase perbaikan. Penelitian di atas menunjukkan bahwa ECP dapat dipakai sebagai petanda inflamasi eosinofil, eksaserbasi penyakit alergi dan menilai hasil pengobatan dengan anti-inflamasi.

Untuk menghentikan kerusakan jaringan oleh eosinofil dengan cara menghalangi sel ini terkumpul di jaringan target. Karena bila ia tidak dapat mencapai jaringan target, sel ini tidak akan berbahaya sebab lingkaran visius inflamasi alergi dapat diputuskan. Cetirizine adalah obat yang telah digunakan pada studi ETAC dan telah terbukti secara signifikan mengurangi migrasi sel eosinofil menuju jaringan target.

\section{Gejala Klinis Asma Anak}

Mengi dan sesak napas adalah gejala klasik asma bronkial, tetapi tidak demikian pada bayi dan anak. Sering gejala batuk pada malam hari dan episode mengi yang berulang merupakan gejala utama dan kemungkinan penyakit lain telah disingkirkan. Asma adalah reaksi inflamasi menahun saluran napas dan inflamasi memegang peranan utama sehingga berkembang menjadi mukosa bronkus yang hiperaktif, artinya mudah terangsang faktor non spesifik seperti asap rokok, bau-bauan, perubahan cuaca emosi, infeksi virus yang memberikan gejala asma. Secara patologis asma disimpulkan sebagai chronic bronchial inflamation.

\section{Kesimpulan}

- Reaksi inflamasi alergi sudah dimulai sejak dalam kandungan

- Faktor dermatitis atopi dan alergi makanan yang merupakan bentuk alergi yang paling dini timbul akan berkembang menjadi asma dikemudian hari sebesar 30-80\%(Allergic March).

- Sebagian mengi pada usia tahun pertama akan menjadi asma di kemudian hari bila terdapat faktor prematuritas pada ibu perokok ketika hamil dan sering mengalami infeksi virus, terutama Respiratory Syncytial Virus

- Faktor genetik berperan pada penyakit asma anak terutama bila ibu juga menderita asma

- Petanda biologis dapat dipakai sebagai alat untuk meramalkan perjalanan penyakit diagnosis, dan hasil pengobatan sehingga dapat dilakukan intervensi dini.

\section{Daftar Pustaka}

1. Dold S, Wjst M, von Mutius E dkk. Genetic risk for asthma, allergic rhinitis, and atopic dermatitis. Arch Dis Child 1992; 67:1018-35.

2. Lee BW. Respiratory disorders in childhood. Leading the way, UCB Bali, February 3, 1999.

3. Siregar PS. Spektrum penyakit alergi di Bagian Ilmu Kesehatan Anak FKUI-RSCM. Dipresentasikan pada Simposium Allergy in Year 2000 from Different Point of View 1998. Agustus.

4. Mrazek DA, Schuman WB. Early asthma onset. Risk of emotional and behavioral difficulties. J Child Psychol. Psychiat 1998; 39:247-54.

5. Gern JE, Lemanske RF. Pediatric Allergy. Can it be prevented? Immunol and Allergy Clin North Amer 1999; 19:233-52.

6. Bergmann R dkk. Atopic disease in infancy. The German multicenter atopy study. Dikutip dari ETAC science 5, 1996.

7. Chandra RK, Puri S, Suraaiya C, dkk. Influence of maternal food antigen avoidance during pregnancy and lactation on incidence of atopic eczema in infants. Clin Allergy 1986; 16:563-9.

8. Faith-Magnusson K, Kjellman NI. Allergy prevention by maternal elimination diet during late pregnancy a 5 year follow up of randomized study. J Allergy Clin Immunol 1992; 89:709-15. 
9. Hoo A-F, Hanshen M, Dezateux C, dkk. Respiratory function among preterm infants whose mother smoke during pregnancy. Am J Respir Crit Care Med 1998; 158:700-15.

10. Ziegler RS, Heller S. The development and prediction of atopy in high risk children. Follow up at age seven year in prospective randomized study of combine maternal and infant food allergen avoidance. J Allergy Clin Immunol 1995; 95:1179-95.

11. Oehling A, Cagnani CEB. Food allergy and child asthma. Dikutip dari James JM. Respiratory tract and food hypersensitivity. Immunol and Allergy Clin North Amer 1999; 19:519-32.

12. Bock SA. Respiratory reactions induced by food challenges in children with pulmonary disease. Dikutip dari James JM. Respiratory tract and food hypersensitivity. Immunol and Allergy Clin North Amer 1999; 19:519-32.

13. Siregar PS, Bambang M, Amar WA. Risk factors of respiratory allergy among children with atopic dermatitis. Paediatr Indones 199; 39: 134-44.

14. Sampson HA, Albergo R. Comparison of results of skin test, RAST and double blind placebo controlled food challenges in children with atopic dermatitis. J Allergy Clin Immunol 1984; 74:26-33.

15. Welliver RC, Wrong DT, Sun M, dkk. The development of respiratory syncytial virus specific $\operatorname{IgE}$ and the release of histamine in nasopharyngeal secretions after infection. N Engl J Med 1981; 305:841-6.

16. Kimura M, Tsuruta S, Yoshida T. Correlation of house dust mite-specific lymphocyte proliferation with IL-5 production, eosinophilia, and the severity of symptoms in infants with atopic dermatitis. J Allergy Clin Immunol 1998; 101:84-9.

17. Garofalo R, Kimpen JLL, Wellifer RC, dkk. Eosinophil degranulation in respiratory tract during naturally acquired respiratory syncytial virus infection. J Pediatr 1992; 1120:28-39.

18. Welliver R, Duffy L. The relationship of RSV-specific immunoglobulin $\mathrm{E}$ antibody responses in infancy, recurrent wheezing and pulmonary function at age 7-8 years. J Pediatr 1993; 15:19-29.

19. Pellikan Z, Pellikan F. The late asthmatic respons to allergen challenge. Am Allergy 1986; 56:414-35.

20. Van Neerven RJJ, Edner C, Yessel H dkk. T Cell response to allergens. Epitope specificity and clinical relevance. Immunol today 1996; 17:526-32.

21. Leung DYM. Atopic dermatitis. The skin as a window into the pathogenesis of chronic allergic diseases. J Allergy Clin Immunol 1995; 96:302-18.

22. Hedlin, dkk. Dikutip dari Biological markers. Current and near-term application in atopic diseases 1997. ETAC Science 6.

23. Warner JO. Biological markers new allergic parameters. A presentation to ETAC investigators. Dikutip dari Biological markers. Current and near-term application in atopic disease 1997. ETAC Science 6.

24. Manardo JL. Dikutip dari Discovering the fruits of ETAC clinical study 1996; ETAC Science 4. 